e-makâlât Mezhep Araştırmaları, IX/1 (Bahar 2016), ss. 1-37. ISSN 1309-5803 | www.emakalat.com

Başvuru: 03.04.2016 Kabul: 15.04.2016

\title{
İHYA ISLAH HAREKETLERİ VE SELEFÎLİK İRTIBAATI
}

\section{Hanifi ȘAHİN*}

Öz

İslam toplumlarında 1slah ihya faaliyetleri İslam tarihte siklikla görülmüştür. müceddid hadisi olarak bilinen rivayetler bu düşünce yapısını beslemiștir. "Kaynaklara dönüș, bidatleri terk" şeklindeki söylemler birçok düşünce ekolü tarafindan ifade edilmiștir. Tüm bu ihya çabalarını İslam'ın içyapısı bağlamında "kendini yenileme" olarak değerlendirmek mümkündür. Bunun yanı sira harici etkiler nedeniyle de ihya faaliyetleri olmuştur. Bu faaliyetlerin yoğunlaşt1ğ1 dönem 19. ve 20. yüzyıllardır. Bu dönemlerde Batı'nın teknikte ilerlemesi, din olarak İslam'ın buna neden olduğunun ileri sürülmesi, bu düşünceleri İslam topraklarını sömürgeleştirme arac1 olarak kullanması Müslüman âlimleri yeniden diriliş için harekete zorlamıştır. Bu konuda adlar1 İslami ihya hareketleri ile özdeşleşen Afgani ve Abduh'u ayrıca değerlendirmek gerekir. Onların düşünceleri birçok noktada Müslüman toplumları etkilemiştir. Selefi akımlarla onlar arasinda bir etkilessim olsa da doğrudan bir katkının olduğunu söylemek zordur. Hatta denebilir ki, selefi akımlar Afgani ve Abduh'un doğru anlaşılmasını engellemişlerdir. İhya hareketlerini sadece AfganiAbduh isimleri ya da sadece Günü-

\section{Abstract \\ Relationship Between Salafism And The Movement Of Rivavel And Renewal}

The movement of rivavel (Ihya) or renewal (Islah) has often been seen in Islamic history. It is known as the mujaddid hadith constitute the basis of the structure of this idea. The rhetoric of "return to the sources, abandoning the innovations (bidah)" has expressed by many schools of thought. All these efforts can be evaluated as the "self-renewal" in the context of the internal structure of Islam. In the history of the movement of rivavel, also, external influences have been seen. The period of these activities were concentrated in 19th and 20th centuries. In this period, the technical development of the Western, the claiming the Islam, as a religion, caused it, using this idea, as a tool the colonization of Islamic lands, Muslim scholars have been mobilized for the resurrection. In this regard, Afghani and Abduh who their names are very important in the Islamic revival movements again need to examine. Their ideas have influenced the Muslims societies in many aspects. Although interaction between Salafiyah and them, it is difficult to say there is a direct impact on the Salafiyah. In fact, Salafi movements

\footnotetext{
* Doç. Dr. Atatürk Üniversitesi, İlahiyat Fakültesi, İslam Mezhepleri.

Associate Professor, Ataturk University, Faculty of Theology, Department of Islamic Sects, Erzurum/Turkey (anifisahin@atauni.edu.tr)
} 
müz Ortadoğu alanı ile sınırlandırarak araştırmamak lazımdır.

Anahtar Kavramlar: İhya, Islah, Afgani, Abduh, Selefilik have prevented true understanding of them. The revival movements should not limited specific names and limited area.

Keywords: Rivavel (al Iyha) renewal (al Islah), Afghani, Abduh, Salafizm

\section{Giriş}

Tüm dinlerin tarihinde 1slah hareketleri bir şekilde varlık bulmuş ve önem kazanmıştır. Değişik zaman ve yerlerde ortaya çıkan dinîahlâkî gelenekleşme, gevşeme ve çözülmeler karşısında devamlı gelişen ihya hareketleri, toplum içinde görülen bu tarz gevşemelere karşı koymak üzere dinin devamının sağlanmasına ve iç hayatiyetini muhafaza etmesine delalet eder. ${ }^{1}$ Yaşanmışlik hali, süreçler, ister istemez din anlayışında bir takım bozulmalara neden olur. Din, ona inananların arzuları, zihnî yapıları istikametinde bir değişikliğe uğrar. Corci Zeydan (v.1914) bu durumu değerlendirirken toplumu dönüştürmede en etkili unsur olarak gördüğü "din adamları" sınıf1nı ikiye ayırmaktadır. Birincisi, dini vazeden veya tebliğ eden peygamberler; ikincisi, dinin sosyal boyutta kazandığı değişme ve bozulmaları ortadan kaldırarak onu aslına irca etmeye çalışan muslihlerdir. Ona göre bozulduktan sonra din o hale gelir ki, onu 1slah etmek, yeni bir din ortaya koymaktan daha zor olur. ${ }^{2}$

İhyacılar, öncelikle dinin inanç ve uygulamada temel dini esaslardan uzaklaşılmış olduğu iddiasını dillendirirler. Din nazariyesi ile ilgili bu itiraz, dini sonradan yapilan ilave ve tahriflerden temizleyerek eski saf haline irca etme gayesini amaçlar. Kısaca her dini ihya hareketinin ilk safhası, tartışmasız inancın aslına dönmeyi savunur. Bu durumdan çıkış yolu ise dine sonradan karıştırılmış her inanç unsurunun atılmasıdır. ${ }^{3}$

\footnotetext{
1 bkz. H. Ezber Bodur, "Dinî İhya Hareketi Olarak Vahhabiliğin Doğuşu, Gelişmesi, Sosyo-Politik, Ekonomik Neticeleri” (Doktora Tezi, Erzurum, 1986), 1.

2 Bkz. Corci Zeydan, Teracimu Meşâhîru'ş-Şark fi'l-Karni't-Tasi Aşere (Hindevi, Misir 2012), 1: 325

${ }^{3}$ H. Frayer, Din Sosyolojisi, çev. T. Kalpsüz, (Ankara 1964), 60-61.
} 
Islah anlayışının İslâm düşüncesinde temel referans noktası müceddid hadisi olarak da meşhur olan rivayetlerdir. Hadiste "Allah Teâlâ, her yüz sene başında bu ümmete, dini tecdid edecek insanlar gönderecektir." ${ }^{4}$ denilmektedir. Bu hadisin oluşturduğu muhayyileden hareketle İslam toplumlarında müceddidsiz bir zamanın tasavvuru dahi düşünülemez; bu durum, bir fetret hali olarak değerlendirilir. ${ }^{5}$

Islah ya da ihya çalışmalarının başlangıç noktası konusunda çok sayıda durum ve isim işaret edilmektedir. Ancak bu işe Gazzâli (ö.505/1111)'nin ihya teşebbüsleriyle başlamak yerinde olacaktır. ${ }^{6}$ İslâm tarihinde ihya hareketleri genel bir eğilim olarak Gazzâlî'nin sentezci sünnî 1slahatıyla başlatılır.7 Gazzâlî, ihyac1 bir düşünür olmayı hak edecek bir şekilde, İslam görüntüsü altında inanca sızmaya çalışan gayri İslâmî unsurların varlığına dikkat çekmiştir. İslâm'ın esaslarına bağlı kalmak şartıyla fikhî meselelerde teferruata ait farklılıkların pek önemli olmadığını belirtmiş, mezhep mensupları arasındaki sürtüşmelerin vahametini dile getirmiştir. Hiçbir delile dayanmadan bilinçsizce kabul edilen imanın şüphelerle dolu olacağını, insan için en önemli özellik olan imanın bilinçli bir şekilde oluşması gerektiğini beyan etmiştir. Ayrıca mezheplerin zayıf taraflarını göstermek suretiyle içtihat ruhunun yeni baştan canlanması için çalışmıştır. Gazzâli'nin ihya düşüncesinde bazı alanlar eleştiri merkezi olarak seçilmiştir. Nitekim o, ahlaki çözülme üzerinde durmuş, dünya ilmi halini alan fikha itiraz etmiş, kelamı din

4 Ebu Davud, Melahim 1, II.

5 Bkz. Eşref Edib, "Dinde Reformcular", Dinde Reformcular, Haz. E. Edib, A. F. Başgil, N. Topçu ve diğerleri, (İstanbul: Sebilurreşad Neşriyatı, 1959), 26.

${ }^{6}$ Gazzâli'nin ihya ve dini düşüncenin yenilenmesi konusundaki görüşleri hakkında detay için bkz. M. Zeki İşcan, "Gazali'nin İhya ve Islah Düşüncesine Genel Bir Bakış", Diyanet İmi Dergi, 47 sy. 3 (2011), 115-134; a.mlf., "Dini İhya ve Islah Düşüncesinde Gazali'nin Önemi”, Süleyman Demirel Üniversitesi Uluslararası Modern Çağ ve Gazzâlì Sempozyumu (12-14 Mayıs 2011), (Bildiriler Kitabı 2014), 37-48.

7 T. Waardenburg, "Official and Popular Religion in Islam", Social Compass, V. XXV, no. 3-4, (1978), 316. 
nazariyesinde bir sapma olarak görmüş ve felsefeyi ise din nazariyesine bir tehdit olarak değerlendirmiştir. ${ }^{8}$

Gazzâli'ye kadar olan sürecin İslam medeniyetinin düşüncede zirve olduğu ve ondan sonra durağan bir düşünce haline geldiği ifade edilmektedir. Hatta Gazzâli'den sonra Endülüs ve İran havzasinda İbn Haldun (ö.808/1406) ve Molla Sadra (ö.1050/1641); Anadolu'da Osmanlı'nın siyasi ve askeri olarak yükselişi, İmam Birgivî (ö.981/1573) gibi isimlerin varlığına rağmen durağanlık aşılamamıştır. Bu nedenle Gazzâli ile Cemaleddin Afgânî (ö.1897) arasındaki geçen yaklaşık sekiz yüz yıl, İslam kültür ve medeniyetinin esas itibariyle kendini tekrar ettiği ileri sürülmüştür. ${ }^{9}$ Gazzâli -Afgânî arasındaki dönemde İslam dünyası tasavvuf, Eş'arilik ve Selefiliğin vektörel bileşkesinden oluşan "irrasyonelin", Cabiri'nin deyimiyle "hermetik atıl aklın" hâkimiyeti altına girmiştir. ${ }^{10}$ Cabiri bu durumu "burhana" karş1 "beyan ve irfan"ın zaferi olarak tanımlamaktadır. ${ }^{11}$

\section{Tanımlama Problemi ve Tarihi Arka Plan}

Gerek batıda gerekse doğuda Muhammed b. Abdilvehhab (ö.1206/1792)'a nispet edilen hareket ile Cemaleddin Afgânî ve ardindan Muhammed Abduh (ö.1905) ${ }^{12}$ ile temsil edilen hareketleri tanımlamada, konumlandırmada bazı zorlanmaların olduğu görülmektedir. Bunlar bir birlerinin devamı mıdır? Bunların İbn Teymiyye (ö.728/1328) ile irtibatı nedir? gibi çok sayıda sorular sorulmak-

8 Detay için bkz. Ebu'l-Ala Mevdudi, İslâm'da İhya Hareketleri, çev. A. Ali Genç, (İstanbul: Pınar Yay, 1986), 82-85.

9 R. İhsan Eliaçık, Adalet Devleti: Ortak İyinin İktidarı, (İstanbul: İnşa Yay, 2011), 308.

10 Bkz. Muhammed Abid el-Cabiri; Arap Aklının Oluşumu, çev. İbrahim Akbaba, (İstanbul: 1997), 259-307.

11 Cabiri, Arap-İslam Kültürünün Akıl Yapısı, çev. Bürhan Köroğlu-Hasan HacakEkrem Demirli, (İstanbul: 2000), 691.

12 Hayatı ve görüşleri hakkında detay için bkz. Muhammed Ammara, el-İmam Muhammed Abduh: Müceddidü'd-Dünya bi Tecdidi'd-Din, (Beyrut: 1985), 2425; M. Zeki İscan, Muhammed Abduh'un Dini ve Siyasi Görüşleri, (İstanbul: 1998), 17-18. 
tadır. Özellikle İbn Abdilvehhab'ın hareket tarzının siyasetle iç içe oluşu, bunu diğer 1slah/ihya hareketlerinden ayrı değerlendirmeyi zorunlu kılmaktadır. Dahası ihya hareketlerinin ortaya çıkışında hepsinin aynı motivasyondan beslendiğini ifade etmek de mümkün görünmemektedir. Örneğin İbn Abdilvahhab'in düşünce sisteminde ihyacılık, dışlamacı bir söylem şeklinde görev icra etmiştir. Oysa Afgânî ve Abduh'da ihya ya da 1slah çabalarında "kriz"e çözüm bulma kaygısının olduğu görülmektedir. İbn Abdilvehhab'in, dinin yenilenmesi çağrısı siyasal bir duruşun sonucudur. Vehhâbîlik, İslami safiyet bayrağı altında Müslüman toplumun daha yüksek bir siyasal örgütlenme düzeyine geçmesine karş1 çıkıştır. Vehhâbîlerin bidat deyip karşı çıktıkları hemen her şey, ilerleme eserleridir. ${ }^{13}$ Gerçekte bu hareket, İslâm'ın Araplık dışı düşünce izlerinden arındırılması gayesi ile başlamıştır. ${ }^{14}$

İbn Abdilvehhab'in bidat, şirk ve gerçek tevhit üzerinde duruşu, dini aslına irca üzerinde yoğunlaşması, siyasal açıdan şu manaya gelmekteydi: Osmanlı hilafeti gerçek dini temsil etmemektedir. Bu yüzden Osmanlıya karşı ayaklanmak vaciptir. ${ }^{15} \mathrm{Bu}$ vurgu, 1slah arayışlarının oluşturduğu bir zeminde; bir yandan sömürgecilere karşı duruşu, diğer yandan Osmanlı karşıtlığını ve Arap milliyetçiliğini, öte yandan geçmişe sarılarak var kalabilme çabalarını içinde barındıran farklı eğilim ve arayışların ifadesi olarak ortaya çıkmıştır. Bu sebepten, Selefiyye'yi tarihin derinliklerine taşımak da, Vehhâbîlikle özdeşleştirmek de, Muhammed Abduh'uh çabalarıyla irtibatlandırmak da oldukça zordur. ${ }^{16}$

13 Kemal Karpat, İslam’ın Siyasallaşması, çev. Şiar Yalçın, (İstanbul: Bilgi Üniversitesi Yay, 2001), 39-41.

14 Hamit İnayet, Arap Siyasi Düşüncesinin Seyri, çev. Hicabi Kırlangıç, (İstanbul: Yöneliş Yay., 1991), 10

15 İşcan, "Selefiliğin Şiilik Değerlendirmeleri Bağlamında Nefret ve Şiddet Söylemi”, e-makâlât Mezhep Araştırmalar, 6 sy. 2 (2013), 156.

16 Hasan Onat, "İslâm Ortak Paydasını Kaybetmiş Müslümanların Açmazı: Şî̀̂Selefî Kutuplaşması", Tarihte ve Günümüzde Selefilik Milletlerarası Tartışmalı İlmî Toplantı (08-10 Kasım 2013), (2014), 538. 
$\mathrm{Bu}$ tebliğde selefilik ile ihya hareketleri arasındaki irtibatın ne olduğu yönündeki net cevaplar yerine bazı sorular sorarak meseleye başlamanın daha doğru olacağı düşünülmektedir. Literatürde Afgânî ile başlayıp günümüze kadar gelen yaklaşık bir buçuk asırlık dönem ihya, ıslah, İslam modernizmi ve çağdaş İslam düşüncesi gibi kavramlarıyla karşılanmaktadır. Biz, bu kavramların Batı'nın her türlü kuşatması karşısında İslam’ı savunma amacına sahip tüm grupları tanımlamak üzere kullanıldığını düşünmekteyiz.

Bazı kavramlar vardır ki, onlarla hem kavramın medlulünü hem de yaslandığı geleneği tanımak, sahip olunan zihniyetleri ele alıp değerlendirmek ve kavramlar üzerinden bir düşünce yapısını yarg1lamak mümkündür. Bugün için İslam, Selefilik, Şia, Vehhâbilik, Siyasal İslam, İhya, modernist, Sünnet-i Seniyye, Ehl-i hadis vb. kavramlar bunlardan bazılarıdır. Bu kavramlar, diğer topluluklar karşısında İslam imajının ve imgesinin nasıl olması gerektiğini belirleyen, bir bütün olarak İslam'in mahkûm edilmesine ya da baş tac1 edilmesine yol açan kavramlardır. Kavramlar bir düşüncenin ne olduğunu tanımlamada önemli birer enstrüman oldukları kadar suçlama, sövme ve hakaret etme aracı olarak da işlevseldir. Tarih bize göstermiştir ki, insan kelimelerle yalnız eşyayı değil, aynı zamanda ihtiraslarını, sevgi ve nefretlerini de dile getirmiştir. ${ }^{17}$

Her oluşumun, oluşum sürecine etki eden ve daha sonra düşünce sisteminin omurgasını oluşturan temel kavramları, ana düşünceleri mevcuttur. Herhangi bir zihniyetten ve mezhebi oluşumdan söz edebilmek için, o oluşumun fikirlerinin hangi zaman diliminde toplumda yer tuttuğunu, nasıl bir süreçte teşekkül ettiğini, hangi kavramlarla kendisini ortaya koyduğunun tespiti önem arz etmektedir. Müslümanların yaygın tarih algısında, önceki kavram ve fikirlerin, daha sonraki olaylarla ve oluşumlarla kolaylıkla irtibatlandırıldığ ile ilgili pek çok örnek bulmak mümkündür. Bunun tersi de görülmektedir; daha sonra oluşan fikir ve kavramlar, daha önceki birtakım olaylarla kolaylıkla irtibatlandırılabilmektedir. İşte ih-

17 Kavram-zihniyet ilişkisi hakkında detay biçin bk. Hanifi Şahin, İk Dönem Şii Kaynaklarda Sünni Algısı, (Ankara: Berikan Yay, 2015), 156-172. 
ya/selefilik, ıslah gibi kavramların yaşadığı süreçler buna birer örnektir. Bu kavramlar duruşlarına ve düşüncelerine meşruiyet alanı açmak isteyenler tarafından kendi paradigmaları eşliğinde okunmaktadır. Burada göz ardı edilen gerçeklik şudur: Her mezhep, her zihniyet teşekkül ettikten, fikirleri toplumda yer tutmaya başladiktan sonra, hem geçmişe doğru kök salar, hem de geleceğe doğru filiz verir. Bir başka ifadeyle, her mezhep, her zihniyet, kendisi ile birlikte kendi tarihini ve geleceğini inşa eder. Bu doğrultuda tarihin geriye doğru işletildiğini, tarihle birlikte geçmişle ilgili algının da yeniden kurgulandığını unutmamak önemlidir. ${ }^{18}$

İslam dünyasının son asırlarına mührünü vurmuş olan dinî yenileşme ve modernizm çabaları için kullanılan kavramlar çoğu zaman birbirine karıştırılmıs ve hiçbir sistematiğe tabi tutulmadan biri ötekine tercih edilegelmiştir. Bu tercihte ön plana çıkan husus ise bu kavramları ortaya atan yenilikçilerin fikrî çizgileri olmuştur. Bazı eserlerde ise "1slah" kavramı daha çok İslam dişı unsurları temele alması anlamıla, Batı'daki reform ile özdeşleştirilmekte, yenileşme ile ilgili diğer kavramlarla birlikte geleneğe olan yakınlıklarına göre bir sıralaması yapılarak "teceddüt, tecdit ve 1slah" şeklinde bir derecelendirmeye gidilmektedir. Bir başka örnekte bunun tam tersi yapılmaktadir. Muhammed el-Behiy, 1slah kavramina, "kendi özgün değerlerini açığa çıkarma çabası" olarak olumlu bir mana yüklerken, tecdit ve reform kavramlarına "İslam'1 yabancı bir düşünce biçimine uydurma" gayreti şeklinde olumsuz bir anlam yüklemektedir. ${ }^{19} \mathrm{Bu}$ derecelendirmeler, ciddi anlamda herhangi bir delile dayanmamaktadır. Hâlbuki yenilikle ilgili kavramların kelime köklerine bakıldığında İslam düşünce tarihini bütünüyle gözden geçirdiğimizde durumun hiç de öyle olmadığı görülecektir. ${ }^{20}$

18 Bkz. Onat, "Şî̂-Selefî Kutuplaşması”, 532.

19 Muhammed el-Behiy, İslami Direniş ve Islahat, çev. İbrahim Sarmış, (İstanbul: 1997), 169-174.

20 İbrahim Maraş, "İslam Dünyasında Yenileşme Arayışları”, İslam Düşünce Ekolleri Tarihi, (Ankara: Ankuzem Yay, 2005), 398. 
İslam düşünce geleneğinde yenileşme hareketleri tartışıldığında birbirlerinin yerine kullanılan üç önemli kavram söz konusudur. Bunlar Cedit, Islah ve İhya kavramlarıdır. Bu kavramlardan Cedit, lügat anlamı itibarıla; eskinin zıddı olarak, yeni anlamına gelmektedir. Aynı kelimenin bir başka türevi olan tecdit ise; yenilemek, bir şeyi eski haline kavuşturmak gibi anlamları sahiptir. Aynı kökten gelen müceddit ise yenileyen veya bir şeyi eski haline kavuşturan kişi için kullanılmaktadır. ${ }^{21}$

Islah kelimesi, lügat anlamı itibarıyla, fesadın zıddı olarak, düzeltmek, kusur ve noksanını, fenalığını gidermek, bozuk yerleri kemâle kavuşturmak, onarmak ve hastayı sıhhate kavuşturmak gibi oldukça geniş bir anlam çerçevesine sahiptir. ${ }^{22}$ Islah kelimesi Kur'an-1 Kerim'de de yer almaktadır. Ayetlerde geçen 1slah kelimesi; ferdî ve toplumsal anlamlarıyla, kişinin benliğinden başlayıp topluma kadar yükselen bir mana ifade etmektedir. ${ }^{23}$ En nihayetinde 1slah; esas olarak bir şeyi daha önceki iyi haline çevirme anlamına geldiği gibi bozulan hususların yerine, eskiden bulunmayan, yenilerini koymak manasını da taşımaktadır. Böylece 1slah kelimesi, tıpk1 tecdit kelimesinde olduğu gibi iki yönlü bir manayı içermektedir. Bunlardan geçmişe dönük olanı, genel anlamıla selefe, yani kendisinden önceki geleneğe bakış açısını içinde barındırırken diğeri, yani geleceğe dönük olanı ise hem yeni içtihatları, yorumları hem de evrensel bilgi ve kültür birikiminin ürünlerinden faydalanmayı ortaya koymaktadır. İki kavramın lügat anlamları, İslâm düşüncesindeki ıstılâhî anlamlarını da şekillendirmiştir. ${ }^{24}$

21 İbn Manzur, Ebü'l-Fazl Muhammed b. Mükerrem b. Ali el-Ensârî, Lisanü'lArab, (Beyrut: Dâru Sadır, t.y. 2: 516-17; Hüseyin Kazım Kadri, Türk Lugati, (İstanbul: 1928, 2: 288, 3: 107-115; Seyyid Ebü'l-A'la Mevdudi, İslam'da İhya Hareketleri, çev. A. Ali Genç, (İstanbul: 1995), 43-45; İbrahim Maraş, "İslam Dünyasında Yenileşme Arayışları", İslam Düşünce Ekolleri Tarihi, Editör. Hasan Onat, (Ankara: Ankuzem, 2005), 399.

22 İbn Manzur, Lisanü'l-Arab, 2: 516-17; Kadri, Türk Lugati, 3: 322-325.

23 Örnekler için bkz. el-Bakara 2/228; el-En'am 6/48; el-A'râf 7/170; elHucurât 49/9

${ }^{24}$ Maraş, "İslam Dünyasında Yenileşme Arayışları", 400. 
İhyâ ise kelime olarak canlandırma, diriltme, ölü toprak üzerinde tasarrufta bulunma, ölü araziyi ekip dikme ve sufi literatüründe de nefsin ilahi nurlarla nurlanması, tecellilerin ortaya çıkması gibi anlamlara gelmektedir. ${ }^{25}$ Burada dikkat çekici ortak nokta, bir şeyin gerçekte var olan temel özelliğine kavuşma anlamıdır. Çünkü toprak üretime müsait olduğu halde kimse tarafından işlenmediği için ölü arazi hükmüne girmiştir. Sûfi, özünde sahip olduğu ilahi cevhere, kendisini arındırmak suretiyle ulaşmaya çalışmaktadır. Nitekim İslam düşüncesinde "dini ilimleri yeniden canlandırma" anlamına gelen İhyâu Ulûmi'd-Din isimli kitabın yazarı İmam Gazzâlî'nin ihya kavramıyla anlatmaya çalıştığı da budur. Yani Gazzâlî, gerçek ilimlerin ve selef-i salihinin takip ettiği ahiret yolunun artık unutulduğunu söyleyerek bunları "ihya" etmekten bahsetmektedir. Buna göre Müslümanları içine düştükleri dini, ahlâkî ve kültürel yozlaşmadan ve bunların içtimâî ve siyasî yansımalarından kurtarmaya çalışmak, dini anlayışı ihya etmek demektir. ${ }^{26}$

Selef ise ilk dönem kaynaklarında ehlü's-sünne ve'l-cemaat ${ }^{27}$, ehlü's-sünne, ehlü'l-hadis, ehlü'l-eser, ehlü'l-ittiba ${ }^{28}$ et-tâifetül'mansûra, ${ }^{29}$ firka-i nâciye, ${ }^{30}$ şeklinde sunulmaktadır. Bu tanımlardan hareketle selefin sadece hadiste ifade edilen ilk üç nesli kastettiği anlassılabilir. Ancak menhec kelimesi merkeze alındığında yani ilk üç neslin takındığı tavır, metot esas alındığında yaşanılan zaman diliminin önce veya sonra olması bir anlam ifade etmez yani kitap ve sünnette yapıssmak temel kriterdir, ashab arasında da olsa bu

\footnotetext{
25 Bkz. Tehânevî, Kitabu Keşşafi Istılahati'l Fünûn, (İstanbul: 1984), 40.

26 Maraş, "İslam Dünyasında Yenileşme Arayışları”, 393-490, 401.

27 İbn Ebü'l-İz, Ali b. Ali b. Muhammed ed-Dımaşki, Şerhu't Tahaviyye fi'l Akideti's- Selefiyye, (Beyrut: 1988), 336.

28 Şehristani, Ebü'l-Feth Taceddin Muhammed b. Abdülkerim, el-Milel ve'nNihal, (Beyrut: 1980), 2: 46.

29 İbn Teymiyye, Mecmu, 3: 157.

30 İbn Teymiyye, Akidetü Ehli's-Süne ve'l- Firkati'n-Naciye, (M1sır: 1385), 10-11.

30 Selefilik: İslami Köktenciliğin Tarihi Temelleri, (İstanbul: Kitap Yayınevi, 2006), 28-32.
} 
şekilde davranmayan selef olamayacağı gibi iki kaynağa yapışmak sonra bile olsa selef olarak nitelendirmek mümkündür ve bu şekilde hareket edecek insanlar kıyamete kadar varlığını koruyacaktır. ${ }^{31} \mathrm{Bir}$ başka ifadeyle selefilik, Hz. Peygamber dönemini ve ilk üç kesimler Hz. Peygamber nesli kendisine ideolojik malzeme olarak benimseyenler anlamina gelir. Kendilerine bu tanımlamayı dayanak edinen kesimler Hz. Peygamber döneminde yaşamamışlar, sadece kendi ideolojilerini o döneme izafe etmişlerdir. Bundan dolayı "selefi" tanımlaması yerine "selefçi" ifadesini kullanmak yerinde olacaktır. ${ }^{32}$

İbn Teymiye'deki kullanıma bakıldığında Selefiyye'nin oluşmuş bir yapıdan, bir hareketten ziyade dışarıdan İslam düşüncesine karışan yabancı unsurlardan dini temizleme ve ilk İslam toplumunun saflı̆̆ına dönme niyetine tekabül ettiği söylenebilir. İbn Teymiye'de Selefi cihet (el-cihetü's-selefiyye), dinin asıllarında aklın kullanımını esas alan yeni yönelişler (el-cihetü'l-bid'iyye) karşısında, Kitap ve Sünnet'e dönmektir. Nebevi ve Selefi yol (et-tarikatü'n-nebeviyye esselefiyye) Allah hakkında re'y ile konuşmamak, Sahabe ve Tabiin'in yolunu takip etmektir. Mantıkî kıyas veya Yunan mantığı, felsefe ve kelamı bırakıp ‘İlm'e tabi olmaktır. Selefiyye, bilhassa haberi sıfatlarda Kur'an ve sünnetin zahirine yapışmak, Sahabe ve Tabiinin sarılmadığ tevilden uzak durmaktır. İbn Teymiye'ye göre Allah kendini nasıl vasfetmissse, Rasulullah O'nu nasıl anlatmışsa bunları öylece kabul etmek lazımdır. es-sabikûne'l-evvelûn' (Sahabe) bu konuda Kur'an ve Hadisin dişına çıkmamışlardır. Mezhebu's-Selef, ta'dil (Allah'in sıfatlarını kabul etmeme) ile temsil (Allah'ı yaratıklara benzetme) arasında orta bir yol tutmuştur. İşte Selefi yol (ettarikatu's-selefiyye) budur. Selefiyye mezhebi (el-mezhebu'sselefiyye) örneğin "Allah semavat ve arzın nurudur" ayetindeki

\footnotetext{
${ }^{31}$ Müfrih b. Süleyman el-Kavsi, el-Menhecü's-Selefi, Daru'l-Fazile, (Riyad: 1422/2002), 41.

32 S1dd1k Korkmaz, "Selefiliğe Karş1 Reddiyeler", Tarihte ve Günümüzde Selefîlik Milletlerarası Tartışmalı İmî Toplantı (08-10 Kasım 2014), 450.
} 
'nur'u tevil etmemektir. 'Allah dünya semasına iner' hadisindeki 'inme'nin mecaz olduğunu kabul etmemektir. ${ }^{33}$

Selefiyye, Ehlü'l-Eser'in ilk dönemlerde olmayan sonraki bir adlandırılmasına karş1lı gelmektedir. Selefiyye, rivayete dayalı din anlayışı tavrının bir yansımasıdır. Selefiyye, Ehlü'l-Hadis veya Ashabu'l-Hadis gibi dinin delile dayandığını, bu yüzden rivayetlerle gelen hususların muhtevaları tartışılmadan aynen kabulünü, re'y görüş, araştırma ve incelemenin reddini esas almaktır. Ancak İbn Teymiye'deki kullanımı esas alındığında Selefiyye'nin, imam olarak Ahmed b. Hanbel'i kabul etmesine rağmen, asırlar içinde Ehlü'lHadis ve Ashabu'l-Hadis yolunun belirsizleşmesi, basit yapısını yitirmesi ve karmaşıklaşması karşısında, bu yolu yeniden 1slah niyetini de içerdiği görülmektedir. Çünkü İbn Teymiye, bazen EhlülHadis'in cahillerinden bahsetmekte, Hanbeli mezhebi şeklindeki nitelendirmenin yanlışlığına dikkat çekmekte, hatta sahih nakil, sarih akıl'dan söz etmektedir. Fakat gözlemlenebildiği kadar İbn Teymiye'deki Ehlü'l-Hadis'in Selefiyye açılımı satıhta kalmış, özde herhangi bir 1slah söz konusu olamamıştır. Örneğin İbn Teymiye'de 'sahih akıl' 'Kur'an ve onu açıklayan sünnetten başka kurtuluş yoktur' görüşünün bir uzantısıdır. Ona göre esas olan, din ve nakildir. Akıl sadece idrak ve tasdik edicidir. Akıllar türlü türlüdür ve bugünkü akılla yarınki akıl birbirine uymaz. Nakil ise daima birleştiricidir. Dolayısıyla İbn Teymiye'nin 'sahih aklı' onun akla kıymet verdiğinin bir göstergesi sayılamaz. Kaldı ki o bu görüşünü, Fahrettin Razi'ye dayandırılan, bir nevi akılc1lık olarak nitelendirilebilecek; 'aklî delillerle sem'î deliller çatışınca akıl tercih olunur. Çünkü 'sem'î deliller yakin bilgi oluşturamazlar' anlayışına bir reddiye sadedinde dile getirmiştir. ${ }^{34}$

Selefiyye konusunda, doğru bilgiye sahip olabilmek ve sağllklı değerlendirmeler yapabilmek için sorulması gereken ilk soru şudur: Selefiyye, bir topluluğu ifade etmek üzere, 1stılah olarak ne zaman,

\footnotetext{
33 İşcan, Selefilik, 26-27.

34 İşcan, Selefilik, 28-32.
} 
nerede, kimler tarafından, kimler için kullanılmıştır; kavramın çekirdek bilgileri nelerdir? Nasıl bir istihale geçirerek günümüze ulaşmıştır? ${ }^{35} \mathrm{Bu}$ sorulara her bir kabul çerçevesi etrafinda cevaplar vermek mümkündür. Ancak görebildiğimiz kadarıyla selefi hareketlerin en önemli açmazları, modern süreçleri yaşamalarına rağmen, kendilerine geçmişle meşruiyet alanı oluşturma gayretleridir. Oysa tanımlama çabamız, geçmişle kurdukları irtibatlarıyla değil "şimdi"de "eyledikleri”yle ilgili olmalıdır. Mevcut selefilik üzerinde bir tanımlama yapmayı zorlaştıran en önemli unsur, günümüz bazı selefi hareketlerin şiddete başvurmalardır. Çünkü kaynaklarda selef-i salihin şeklinde referansla gösterilen selefin şiddetle bir işi olmamıştır. Aksine şiddet, Harici ve gali/uç fırkaların metodu olmuştur.

Selefiyye ile ilgili olarak gerek kavram ve kavramın irtibatlı olduğu zaman dilimi, gerekse içerik konusunda ciddi bir belirsizlik ve karmaş1kl1k olduğu kolayca görülebilmektedir. Bunun en başta gelen sebeplerinden birisi, Selefiyye'nin öncelikle bir zihniyet olduğunun çoğu zaman göz ardı edilmiş olmasıdır. Selefiyye hiçbir zaman bir mezhep hüviyeti kazanamamıştır. Selefiyye'nin çekirdeğini, özellikle çöküş sürecine giren toplumlarda belirgin hale gelen, geçmişe yönelik özlem oluşturur. ${ }^{36}$ Bütün tanımlarda selefiliği geçmişe indirgeyip oraya mahkûm etmek her bir tanımın dayandığı tarihi arka planlarını, hareketlerin yerelliğini ihmal etmektir. Bu da rölatif olan bazı durumların hepsi için geçerli mutlak bir önerme olarak değerlendirmesini, bunun da her bir değerlendirme ve tanım için yeniden ele alınması gereken şartların ihmal edilmesini doğuracağın1 dikkate almak gerekmektedir. Aksi halde tek bir tanımla farklı alan ve gerekçelere dayanan oluşumların izahı, bizi geçmiş mirasına mahkûm ederek meselelerin biricikliğini ihmal etmeye götürür.

Selefiliği tanımlama ve konumlandırmada sıkıntılar olsa da şunu özellikle ifade etmek gerekir ki, Selefilik, sosyal ve siyasi gelişmelere

\footnotetext{
35 Onat, "Selefi-Şii Kutuplaşması", 538.

36 Onat, "Selefi-Şii Kutuplaşması", 537.
} 
uygun olarak din nazariyesinde meydana gelen gelişmeler karşısında bir "itiraz" olarak ele almak ve tarihi sürecini bu açıdan temellendirmek gerekmektedir. Selef düşüncesinin önemli özelliklerinden birinin de şimdiyi tanımlama ihtiyacı duymaması, geçmişte varlığını sürdürmeyi israrla istemesidir. Ancak Cioran'in da dediği gibi öncesiz sonrasız şimdiyi tam tamına benimsemiş olsaydık tarih vuku bulmazdı ya da her hâlükârda ağır yük veya azapla eşanlamlı olmazdı. Tarih üzerimizde aşırı ağırlık ettiği ve bizi bunalttığı zaman, varlığımızı aşağılık bir ödleklik sarar: Yüzyılların ortasında çırpınmaya devam etme ihtimali bir kâbusun boyutlarını alır. ${ }^{37}$

Selefilik nedir, bir mezhep mi, bir zihniyet mi? Her iki sorunun da literatürde karşılığı vardır. Afgânî-Abduh ekolünün asr-1 saadete ve selef nesline vurgu yapan ama modernist eğilimli içeriğinden tamamen ayrı tutarak, klasik Ehl-i Hadis-Hanbeliyye-Vehhabiyye çizgisinin bir devamı olarak tanımladığımızda, 38 tanımın merkezine Suud'u/Vehhâbî düşünceyi koymuş oluruz. Bu tanım, hedef kitlesi dikkate alındığında doğru olabilir, ama selefilik dediğimizde tüm selefileri tanımlamada eksik olacaktır. Özellikle Selefiyyeyi, Afgânî ve Abduh çizgisindeki tecdid ve 1slah arayışları ile birebir özdeşleştirmenin doğru olmadığını söyleyebiliriz.

\section{İhyacılığı Hazırlayıcı Nedenler ve İhyacılığın Düşünce Kodlar1}

İhya düşüncelerinin ilk çıktığı dönemlerde İslam toplumlarının her kesiminde bir karşılık bulduğu görülmektedir. Osmanlı Devleti’nin içine sürüklendiği çöküş süreci, İslam dünyasının çok farklı yörelerinde, birbirinden farklı olsa da, temelde kötü gidişi durdurmayı amaçlayan, "1slahat arayışları" diyebileceğimiz çeşitli eğilimle-

37 Emile Cioran, Tarih ve Ütopya, çev. Haldun Bayrı, (İstanbul: Metis Yay, 2013), 98.

38 Büyükkara, "Günümüzde Selefîlik ve İslâmî Hareketlere Olan Etkisi”, Tarihte ve Günümüzde Selefïlik (Milletlerarası Tartışmalı İlmî Toplantı 08-10 Kasım 2013,) (İstanbul: 2014), 485 
rin, ciddi arayışların ortaya çıkmasına yol açmıştır. ${ }^{39}$ Nitekim bu anlayışın Osmanlı'da ifade tarzı "esâsât-1 kadîme-i İslâmiyyeye rücu" (İslam'in ilk temel esaslarına dönüş) ve "ihtiyâcât-1 zamâniyyeyi müdrik ulemanın cehd ve içtihatlarına" (zamanın gereklerini idrak eden din âlimlerinin gayret ve içtihatlarına) şeklindeki ifade İslamc1lik ile ihyacıların ortak noktalarından biridir. ${ }^{40}$

XIX. yüzyılın son yarısı ile XX. yüzyılın ilk yarısını kapsamakta olan ıslah/ihya faaliyetleri, Osmanlı'nın çöküş yıllarına denk gelmiştir. Tanzimat, I. ve II. Meşrutiyet ve I. Cumhuriyet'in kuruluşu, İslam'ın "gücünün tecelli merkezi" olarak görülen Osmanlı'nın tarih sahnesinden çekilissi bu dönemin en önemli siyasi olaylarıdır. Bu sebeple olsa gerek dönemin İslamc1 muhayyilesinde temel siyasi vurgu "devleti kurtarma" ana teması etrafında şekillenmiştir. ${ }^{41} \mathrm{Ge}-$ rek Osmanlı gerekse Afgânî ve etrafındakiler, Şahveliyyulah Dihlevî (ö.1176/1762)'den devraldıkları erken yenilikçi argümanları devam ettirip geliştirmişlerdir. Temel kaynaklara dönüş, taklidi terk, 1slahat, yenilik, direniş, aklı ve bilimi esas alma, İslami hadaret, İslam Birliği vs. bayraklaştırılan temel sloganlardan bazılarıdır. ${ }^{42}$

İslâm modernizminin ya da İslam ihyacılığının ortaya çıktığı XIX. yüzyıl, özellikle bu yüzyılın ikinci yarısı, İslâm dünyasının, batının o zamana kadar görülmeyen büyük bir meydan okuması ile yüz yüze geldiği bir tarih kesitini ifade eder. Müslümanlar her bakımdan zayıftırlar, kültür soğuma dönemine girmiş, insanlar esaslı bir kimlik bunalımı ile karşı karşıya kalmışlardır. Bu kritik tarih kesitinde bazı Müslüman entelektüeller, iç çöküntü meselesinden hareket ederek yeniden ihya üzerinde durmuşlardır. Onlara göre bu diriliş ancak zihniyet değişikliği ile mümkün olacaktır. Bu da dinî 1slahın sonucunda gerçekleşebilecek bir durumdur. Çünkü zihniyet, akide

\footnotetext{
39 Onat, "Selefi-Şii Kutuplaşması", 539.

40 İşcan, "Batıcıların İslamcılığı "Hüseyin Cahit ve Celal Nuri'nin İslami Yenilik Düşüncesi”, Düşünce Dünyasında Türkiz, 3 sy. 14, (2012), 20.

41 İsmail Kara, Türkiye'de İslamcılık Düşüncesi'nin Temel Metinleri, Gerçek Hayat Dergisi, (ty. yy.) 41-42.

42 Eliaç1k, Adalet Devlet, 307.
} 
ve amel arasında sarsılmaz bir bağ vardır. İslâm akidesi, gerçeğine uygun bir şekilde ortaya konur, dinî nasların yanlış anlaşılması sebebiyle itikada giren hatalar izale edilir, inanç, bid'atlerin tahakkümünden kurtulursa, zihniyetler düzelir. Zihniyetlerin düzelmesi, ameller ve fiillerin fesattan kurtulmasinı da beraberinde getirir. Böylelikle fertlerin ve toplumun hali, 1slah olur. ${ }^{43}$ Bu noktada klasik İslâm çağdaşçıllğında artık konu, bir din olarak İslâm değil, daha çok bir uygarlık olarak İslâm'dır. Önemli olan, her yönü ile beşerî bir uygarlığın yaratılmasıdır. ${ }^{44}$

Avrupa merkezli batı medeniyeti, Rönesans ve reform hareketleriyle kendisini büyük ölçüde yenilemesi; Hiristiyan dogmatizminin toplumsal, kültürel ve siyasal alanda güç kaybetmesi sanayi devrimini kolaylaştırması; bu gelişmeyle Batı'nın, teknik ve ekonomik bakımdan İslâm dünyasına kıyasla büyük mesafeler kat etmesi, Müslüman ülkeler batılı emperyalist devletlerin istilasina maruz kalmaları, 1798'de Napolyon'un Mısır'ı işgal etmesi, 1852'de Hint alt kıtasının İngiliz himayesine girmesi, Kuzey Afrika ülkeleri, Fransa ve İtalya'nın işgaline maruz kalması,1882'de Mısır'n İngilizlerin eline geçmesi, Osmanlı Devleti kapitülasyon anlaşmalarıly birçok ekonomik imtiyazı batılı güçlere devretmesi, girmiş olduğu harplerin ve Fransız İhtilali'nin ateşlediği milliyetçilik hareketlerinin etkisiyle önemli topraklarını kaybetmesi Batı'nın sıçrama yapmasına yol açan önemli gelişmelerdir. ${ }^{45}$

İslam'in saf halinin yaşandığı, en sahih ve en kompleksiz yapıs1nın bulunduğu, itikatta birliğin bozulmadığı, diğer milletlerin kültürlerinin İslam'a girmediği, dinin asıllarını anlamada bir idrak ve düşünce birliğinin olduğu ideal bir devir kurgulama, bugün bile Müslüman bilincinin zaaflarından, yanılgılarından biridir. İhyacıl1ğın en önemli esası selefe dönüş çağrısıdır. Bu çağrıda selef, kutsal-

43 Örnek olarak bkz. Muhammed Abduh, el-İslâm Dînu'l-ĭlm ve'l-Medeniyye, thk: Tahir et-Tenâhi, (Kahire:, ty.), 82-83.

${ }^{44}$ Hüseyin G. Yurdaydın, İslâm Tarihi Dersleri, (Ankara: 1998), 224-225.

45 Detay için bk. Kara, Türkiye'de İslamcılık, 12-16; M Ali Büyükkara, Çağdaş İslami Akımlar, (İstanbul: Klasik Yay, 2015), 22-23. 
laştırılmış, tarihten çok dinin bir parçası haline getirilmiştir. Böyle bir kabul, idealleştirilmiş bir altın çağ imajına yol açmış, tarihin ve toplumun sanki bir ssekilde nüfuz edemediği bir zaman kesitinin varlığ düşüncesini doğurmuştur.

Islah ya da ihya düşüncesinin söylemlerinde sertliğe yönelmeleri, onların kuşatılmış ideolojiler gibi tepki veren insan tiplerine benzemelerine yol açmaktadır. Kuşatılmış insan tipinin davranışları sağlıklı olmayacaktır, aksine inisiyatifi başkasının elinde olduğu için de sağlıklı adımlar atamayacaktır. Bu rahatsız edici durumdan kurtulmak için de geçmişte mutluluğu yakalamış, hakikatin püriten temsilcileri olarak görülmüş selefe vurgu yapilır.

İhyacı anlayışın en önemli özelliklerinden birisi bu düşünce yapisının, taklidi reddetmeyi temel ilke olarak tespit etmesidir. Taklit, dini, sünnetin dişında re'y ile hüküm veren veya Kur'ân'dan, esersiz (rivayetlere dayanmadan) anlam çıkarmaya çalışan kişi veya kişilerden alma şeklinde anlaşılmış, delil olmadan bir kişinin görüşünü benimseme olarak görülmüştür. Taklidin zıttı olan ittiba ise hüccetle sabit olana uymaktır. Buna göre taklit memnu', ittiba ise gerekli bir durumdur. Bu zihniyete göre taklit, 'bilinene (İlm) değil bir manada bilinmeyene (zan) tabi olmaktır. Hâlbuki ilme yani selefin b1raktıklarına tabi olmak esastır. Esere ittiba, bilinen'e ittibadır. ${ }^{46}$ Ehlü'l-Hadis'in oluşmaya başladığ 1 ilk dönemden beri taklidin dişlanması, ashaptan birine dayanmayan dinî anlayışın bid'at kapsamında değerlendirilmiş olmasına dayalıdır. Bu manada sahabe, tabiîn ve etbau't-tabiînin büyüklerinin nakillerine referansta bulunmayan, sadece Kur'ân'dan çıkarıldığı iddia edilen bir hükmü esas almak, taklit olarak nitelendirilmiştir. ${ }^{47}$

İhyacı anlayışta taklit, geçmiş kuşaklara (ilk dönem) tabi olmayı sorgulayan bir ilke değil, tam aksine bu kuşaklara ittibayı öngörerek, reyi, görüşü, akli hükmü din dışına atmaya çalışan bir ilkedir.

\footnotetext{
46 Bkz. İbn Abdilberr, Camiu Beyani’l-İlm ve Fadlihi ve ma Yenbağî fi Rivayetihi ve Hamlihi, thk. Abdulkerim el-Hatip, Dâru'l-Kütübi'l-İslâmiyye, (Kahire: 1982), 452.

47 İşcan, Selefilik, 110.
} 
Taklit reddedilir; çünkü asıl olan Kur'an ve sünnetin zahirine sımsıkı yapışmak, her şeyi bunların zahirinden çıkarmaktır. Eğer akli yorum veya tevil yoluna gidilirse şirk yolu tutulmuş olur. ${ }^{48}$ İhyac11ğın selefe dönüş ve taklidi ret prensipleri, ilahi alanı bir kültür kodunun kıskacına alan, din ile belli bir yaşam tarzı arasında bünyevi ilişki kuran "rivayete dayalı din anlayışı "ndan başka bir şey değildir. Taklidi ret, sosyal hayatın aldığı yeni şekilleri, akıl, görüş bildirme, tevil gibi yollarla değerlendirmeye tabi tutmayı rettir. Bu manada taklidi ret, aslında insanın düşünce alanındaki yaratıcıllğını rettir. Selefi anlayışın tüm esaslarında var olan 'insansızlık', burada da kendini göstermektedir. Düşünemeyen, aklı ile yargıya varamayan, hüküm koyamayan, görüş bildiremeyen bir varlığın 'insan' olarak anılması doğru olmayacaktır.

İhyac1lıkta önem arz eden diğer bir husus, dini bid'atlerden temizlemektir. Bu esas da çoğu zaman dinî düşüncede meydana gelmiş ilerleme esaslarını ret olarak anlaşılmıştır. Bid'at, sünnet karş1sında temellendirilmiş ve sünnet varken yeni yol icadı olarak görülmüştür. Bu anlayışa göre hakikat adına ne varsa hepsi, geçmişte oluşmuştur. 'Şimdi' de ve 'gelecek' te hakikat aranamaz. Bu yüzden bir meselenin halli için 'nassı' temel almak zorunludur. Tek delil, nastir. Yani ya vahiy olacak ya da sahabeden gelen bir haber olacaktır. Yahut geçmiş uluların bir kararı bulunacaktır. Elde 'âhad' da olsa bir haber varsa, ona teslim olunur ve bu konuda tartışmaya girişilmez. Bunun dişına çıkan, 'bid'at ehli'dir49

Bid'atin reddi, gerçekte hakikatin dışsal olabileceğinin inkâr edilmesidir. Hakikat tektir ve bizdedir' anlayışı, yerel unsurların dışına taşan her türlü çabayı, araştırmayı, girişimi, Kur'ân merkezli bile olsa batıl addetmiştir. İhyac1 gelenek, özgün ve bağımsız bir kitap olarak Kur'an'a başvurmayı rey izharı, dolayısıyla bid'at olarak görmüştür. Bunun için bütünleyicilik-retçilik referansına dayalı

\footnotetext{
48 Fığlalı, Çağımızda İtikadi İslâm Mezhepleri, 116-117.

49 İşcan, Dinî "Bir Otorite Olarak Sahâbe Algısı", İslâm Medeniyetinin Kurucu Nesli Sahâbe: Sahâbe Kimliği ve Algısı, Tebliğ ve Müzâkereler, Tartışmalı İmî Toplantl, (27-28 Nisan 2013), (2014), 210.
} 
bid'at karşıtlığı, gelişmeyi inkâr etme temeli üzerine kuruludur. Gelişme ve değişmeyi inkâr eden tavırla entegrizm hemen hemen aynı şeydir. Selefiliğin bid'at anlayışlarından yola çıkılarak denilebilir ki, bu zihniyetin 'dışlama gücü' çok fazladır. Dışlama iktidarı var ama erişim iktidarı minimum düzeyde kalmaktadır. Katılma, erişme, ulaşma gibi kelimeler bu anlayışta fazla yer tutmamaktadır. ${ }^{50}$

İhyacılıkta İslâm'ı hayata yeniden hâkim kılmak da bir başka önemli husus olarak gözükmektedir. Müslümanların gerilemesinin sebebi, İslâm'ın hakikatinden uzaklaşılmış olmaktır. Çözüm, gerçek İslâm'a yönelmek, yani İslamlaşmaktır. Bunun için öncelikle Hz. Peygamber dönemine, asr-1 saâdete dönmek ve temel kaynaklara, Kur'ân ve sünnete başvurmak lazımdır. Sonraki görev ise, asr-1 saâdetin ardından ortaya çıkmış geleneklerin gözden geçirilmesi ve 1slah edilmesidir. İslâm düşüncesini körelten, Müslümanları yanlış yollara sevk eden bid'at ve hurafelerin ayıklanmasıdır. Bu "ana kaynaklara dönüşçü" özelliği nedeniyle "yeni selefilik" veya "islahatçı selefîlik" olarak tanımlanmıştır. ${ }^{51}$

İhyacı düşünce, varlığını temellendirmek için din algısını yeniden şekillendirmenin gayreti içinde olmuştur. Buna göre İslâmiyetin, modern ihtiyaçları karş1layacak evrensel bir siyasi-sosyal muhtevaya sahip olduğu ifade edilerek din olarak İslam'ın bir yük değil, müntesiplerinin hayatlarını kolaylaştıran bir yapı olduğu tezi sıklıkla, ifade edilir hale gelmiştir. İslâmiyet'in modern dünyadaki bu kapsayıcılığı, kaynağını kutsaldan almakla birlikte akılla da kavranıp temellendirilebilir. Zira İslâm, akla uygun bir dindir. Bu nedenle çağın yeniliklerine kolaylıkla intibak edebilir. İslam gelişmeye (terakki) engel olmadığ gibi bizzat gelişmeyi emreder. Dinin gelişmeye engel olan unsurları, dine sonradan ilave edilen geleneğin ürünleridir. Tutucu bağlardan kurtulmak ve asli kaynakları gelişmeci bir dini sistemin hizmetine sunmak için, Ortaçağ'da kapanan içtihat

\footnotetext{
50 İşcan, Selefilik, 32.

${ }^{51}$ Kara, İslamcılık, 41; Büyyükkara, Çağdaş İslami Akımlar, 23-24.
} 
kapısı yeniden açılmalı, yeni hükümler üretilmeli, mezhep taklitçiliğinin önüne geçilmelidir. ${ }^{52}$

İhyacı düşünürler entegrist olmayıp diğer kültür yapılarıyla temastan yana olmuşlardır. Hatta onlara göre Müslümanlar batı toplumlarını üstün kılan ilmi, medeni ve teknik usulleri alarak kendi toplumlarını kalkındırmak zorundadır. Zaten batı medeniyeti bugünkü yüksek seviyesine daha önce Müslümanlardan öğrendikleriyle ulaşmıştır. Hz. Peygamber'in "hikmet müminin yitik malıdır, nerede bulursa onu alır" sözü referans alınmalıdır. Fakat bu yararlanma faaliyeti seçmeci (eklektik) bir tarzda yapılmalıdır. Yabancı ideolojiler ve ahlak anlayışları da bu arada alınırsa, bunlar İslâm'ın asli değerlerine uymadığından, bu tarz bir taklit gelişmeye değil y1kıma sebep olur. ${ }^{53}$

İhyacı gelenekte özellikle tasavvufa bakışta farklılıklar görülmektedir. Tasavvufun yıkıcı tesirleri olduğu, bu nedenle ondan uzak durulması gerektiği sıklıkla dillendirilir. Gelenekle hesaplaşma bağlamında İslâmcılar, genel olarak tasavvuf ve tarikatlara menfi bakmışlardır. Tarikatların atâlet ve miskinlik yuvaları haline geldiği; insan iradesini değersizleştirdiği; hurafeciliği geliştirdiği; takva, tevekkül ve zühd kavramlarını yanlış yorumlayarak ilerlemeye mani olduğu iddiaları sık sık dile getirilmiştir. Ancak felsefi bir boyut taşıması ve bütün dinleri içine alan müsamahakâr birlik anlayışı nedeniyle vahdet-i vücûd düşüncesi bazı İslâmcilar nezdinde özel ilgi görmüştür. ${ }^{54}$

İhya hareketinde tüm düşünülen ve idealize edilen yeniden dirilişin gerçekleşme yolu ve imkânı, işlevselliği nedeniyle eğitimögretimin 1slah edilmesi fikridir. Buna göre bu alan mutlaka 1slah edilmelidir. Onlara göre, medrese sistemini değiştirmek, 1slah etmek, pratik hiçbir faydası olmayan veya devri geçmiş dersler yerine

\footnotetext{
52 Kara, İslamcılık, 41; Mümtazer Türköne, "İslamcıllk", DİA (İstanbul: 2001), 23: 61-62; Büyükkara, Çağdaş İslami Akımlar, 24.

53 Kara, İslamcilık, 41.

${ }^{54}$ Kara, İslamcilık, 41.
} 
günün ihtiyaçlarına cevap verecek konuları okutmak, felsefenin ve pozitif bilimlerin tahsiline önem vermek gerekmektedir. Bu hedefler doğrultusunda Seyyid Ahmed Han, Aligarh Mektebi'ni kurmuş; Muhammed Abduh el- Ezher müfredatının 1slahı için çalışmış, Said Nursî ise Doğu Anadolu'da Zehrâ Medresesi adıyla açmayı düşündügü bir yükseköğretim kurumunu projelendirmiştir. 55

İhya düşüncesinde siyaset alaniyla ilgili olarak, Osmanlı toplumunda da karşıllk bulan İttihad-ı İslâm (pan İslâmizm) ${ }^{56}$ fikri için çalışmak önemle vurgulanır. Onlara göre İttihad-1 İslâm, Müslümanların siyasal birliği, İslâm âleminin geri kalışını ve sömürgecilerin istilasını önleyecek tek çaredir. II. Abdülhamid bunu bir devlet politikası haline getirmiştir. Osmanlı padişahının aynı zamanda ümmetin halifesi olma imtiyazı tahkim edilerek İslâm ülkelerinin maddi ve manevi desteğini celp etmek ve bu sayede Osmanlı devletini emperyalist güçler karşısında ayakta tutmak, bu politikanın esas amacını teşkil etmiştir. ${ }^{57}$

İhyac1 düşünürlerin siyaset alanıla ilgili olarak rahat düşünce üretmelerinde onlara göre Kur'ân ve sünnette belli bir yönetim şeklinin ortaya konulmamış olması katkı sağlamıştır. Nasslar ilkeler düzeyinde siyasete karışmaktadır. Bir devlet modeli ön görmez. Bu nedenle hilafet kurumunu, "peygamber vekâleti" olarak kabul eden geleneksel anlayıştan farklı olarak "millete vekâlet" şeklinde takdim etmişlerdir. Bu yeni yaklaşım halk egemenliğine vurgu yaparak anayasa (kânûn-i esâsî) ve vekiller meclisi gibi yeni kurumları güçlendirmeyi hedeflemiştir. Meşveret, şûrâ, biat gibi İslâmî kavramlar ile batı kökenli demokrasi, parlamento, serbest seçim, kamuoyu gibi kavramların arasında yakın irtibatlar kurularak İslâmcı bir siyaset ideolojisi kurulmaya çalışılmıştır. İslamcılar arasında, temel insan haklarının korunması, Müslüman kadının toplumdaki yerinin

\footnotetext{
55 Kara, İslamcılı, 47; Büyyükkara, Çağdaş İslami Akımlar, 25.

56 Afgani'nin düşünceleri konusunda detay için bkz. Nikki Keddie, Cemaleddin Efgani: Siyasi Hayatı, çev. Alaeddin Yalçınkaya, (İstanbul: Bedir Yay, 1997), 381-412.

57 Büyyükkara, Çağdaş İslami Akımlar, 25.
} 
iyileştirilmesi, oryantalist saldırılara cevaplar yetiştirme ve yabancı akımlarla mücadele etmek için çok sayıda kitap telif eden âlimler olmuştur. ${ }^{58}$

İhyacı düşünürlerin Kur'an'a bakış açıları klasik çizgiden izler taşısa da onların kendilerine özgü bir Kur'an anlayışları olduğu görülmektedir. Onlara göre Kur'an modern bilimle uyumlu bir kitaptır. Kur'an merkezli bir düşünce tasavvuruna sahip ihyacı âlimlerin, ayetleri tefsir ederken Kur'an'i modern bilimle uyumlu bir kitap olarak gösterme gayretinde olduklarını anliyoruz. Bu yorum tarzı, İslâmiyet'in bilimsel gelişmeleri engellediği yönündeki iddialara bir cevaptı. Hz. Mûsâ'nın önünde dağın erimesi haberini Seyyid Ahmed Han'in volkanik bir patlama olarak açıklaması yine Hz. Mûsâ'nın elindeki asasıyla taştan pınarlar akıtmasını Said Nursî'nin artezyenin işareti olarak göstermesi yahut kuşların attığ1 taşlarla Ebrehe ordusunun helâkını Abduh'un bulaşıcı çiçek hastalığı ile izah etmesi, hissi mucizelerin aklîlleştirilmesi ve bilimsel hale getirilmesi gayretinin ilginç örnekleri olarak dönemin eserlerinde karşımıza çıkmaktadır. 59

\section{Selefiliğin Düșünce Kodları}

Selefllik, tarihte ortaya çıkan tüm görüntüleriyle bir dini ihya hareketi sadedindedir. Hadis Cemaati (Ehli hadis), İbn Teymiyye ekolü, Muhammed b. Abdilvehhab hareketi ve birçok yönüyle yirminci yüzyıl İslamcılığı, temel esaslar olarak, dini aslına ircayı, onu bid'atlerden temizlemeyi mezhebi görüşlerden Kur'an ve hadise dönüşü benimsemişlerdir. Zaten Selefilik dendiğinde, ameli açıdan açıklanan bir tevhit ilkesi etrafında şekillenen selefe dönüş, taklidi ret, dini bid'atlerden arındırma esasları anlaşılmaktadır. Bu zihniyette yabancı unsurlardan dini temizleme ve ilk İslam toplumunun saflığına dönme niyeti söz konusudur. ${ }^{60}$ İhya, dinin asıllarında ak-

\footnotetext{
58 Bkz. Kara, İslamcllı, 40.

59 Kara, İslamcılık, 42, 47-49; Büyyükkara, Çağdaş İslami Akımlar, 26.

60 İşcan, "Selefîliğin Temel Esasları ve Sosyo-Politik Arka Plan", 93.
} 
lın kullanımını esas alan "yeni yönelişler" karşısında, Kitap ve sünnete dönmek, rey ile konuşmamak, sahabe ve tabiinin yolunu takip etmek, felsefe ve kelamı bırakıp 'ilm'e yani geçmişte (selef dönemi) atalar tarafından tecrübe edilen bilinenlere tabi olmaktır. ${ }^{61}$

Selefilik, "dışarıdan almaya" karşı, "İslam'ı" ihya etme niyetine tekabül etmektedir. Bunu tanımlayan iki unsur vardır. Birincisi, her şeyin Kur'an'a, sünnete ve şeriata indirgenmesi, mutlak bir lafzilikle kaynakların ele alınmasıdır. Selefilikte insanın fiil ve davranışlarının bütünü din içinde değerlendirilir. İkincisi, saf geleneğe ilave edilen her şeyle ilgili olarak sapıklık gibi gördüğü, bida’ ya da yeniliktir. İlave edilen şey zararsız bile olsa gerçekte Selefilik, kökten silip atmak istemektedir. ${ }^{62}$ Selefilikte İslami özne (gerçekte nesne), "evet" insanı değildir; etki eden değil tepki veren, nefret biriktiren hayır insan1- dır. Selefiliğin geçmişten günümüze en önemli özelliği, militan retçiliktir. Selefilikte toplum bir mağaradır ve bu mağaranın duvarlarını din ve moralite inşa etmektedir. ${ }^{63}$

Selefi zihniyetin en belirgin özelliği onun kolektif ve epik İslami yöneliş türü olmasıdır. Kolektiftir çünkü keskin sınırları olan "biz" kavramından yola çıkmaktadır. Epiktir çünkü epik bir geçmişe (asr1 saadet) dayalı mutlak bir gerçekliği dillendirmektedir. Selefi yöneliş, yaratanın elinden çıkmış olarak hayatın "geçmişte", Allah ve Resul'ünün kutsadığ ilk nesiller eliyle tamamlanmış olduğunu varsaymaktadır. Bu zihniyette "şimdi" ve "gelecek", "geçmiş" zaman içinde anlam kazanır; insan ferdi ve toplum için amelin tek bir hüküm standartı vardır; o da geçmişte ortaya konmuş "âsâr'dır. Din "âsâr'dır. Selefiliğin iki önemli özelliği nasçılık ve katı ahlakçı tavrı, kurulmak istenen cemaatin sınırlarını tayin etmektedir. Nasçılık ve katı ahlakçı tavır, "yöresel homojenliği" koruma amacına yöneliktir. Hadis cemaati, belli bir hayat biçimini hayatın değişen çehrelerine karşı bir protest hareket olarak onayanlardır. Burada hadisin ya da

\footnotetext{
61 İbn Teymiyye, Mecmüu Feteva, 12: 349-350, 16: 471-476.

62 Olivier Roy, Küreselleşen İslâm, çev. Haldun Bayrı, Metis Ya, (İstanbul: 2003), 125.

63 İşcan, "Selefîliğin "Temel Esasları ve Sosyo-Politik Arka Plan", 91.
} 
dini metnin rolü ikincildir. Çünkü hayat biçimi söz konusu olduğunda hadisi Kur'an karşısında bile temellendirmek mümkün hale gelmiştir. Kur'an'ı hadise göre anlamak, belli bir yaşam tarzına göre anlamakla eş anlamlıdır. ${ }^{64}$

Selefilik, ödünç alınmış bir zihniyetle meselelere bakmaktır; Selefe itiraz, aşina olunan dünya ve söylemlere bir kafa tutuştur. Selefe vurgu yapmak, "bizi ilk bahçenin mutluluk dolu sersemliğine sokar"; 65 anlam yüklediğimiz o altın çağın kahramanlarının sırlarına vakıf olmayı erdem olarak görmek isteriz. Selefle uyum sağlayan, "özdeşleşen kişi, "evrensel uyum”un gelissine bel bağliyormuş ya da kendini bunun başlatıcısı zannediyormuş gibi davranır. ${ }^{66}$ Selefilik, tepkiselci ve entegristtir, zira İslam'in hinterlandında yer almaya başlayan yeni kültürlerle kurulan temasta sahip olunan birikimin elden gideceği dolayısıyla da güven duygususun kaybolacağı bir durum oluşacaktır. İslam'ın ilk muhatapları olan Arapların bu güven duygusunu kaybetmemek için atalarının çöldeki ayak izlerini bile takip etmeyi ilke sayan ${ }^{67}$ bir bakış açısına sahip olduğu düşünülürse diğer medeniyetlerle kurulan temasın rahatsız edici olması normaldir. Selefilik nihayetinde "güvenli yol" arayışıdır.

Selefe dönüş, hemen hemen tüm selefi yönelişlerde idealleştirmiş bir "altın çağ" imajına yol açmıs, tarihin ve toplumun sanki bir şekilde nüfuz edemediği bir zaman kesitinin varlığ düşüncesini doğurmuştur. Taklidi ret, ilme, yani önceden atalar tarafından tespit edilmeyen yeni şeylere tabi olmayı ret anlamı taşımıştır. Taklidi ret, sosyal hayatın aldığı yeni şekilleri, akıl, görüş bildirme, tevil gibi

\footnotetext{
64 İşcan, "Selefîliğin “Temel Esasları ve Sosyo-Politik Arka Plan”, 93, 101.

65 Cioran, Tarih ve Ütopya, 99.

66 Cioran, Tarih ve Ütopya, 103.

67 W. Montgomery Watt, İslam Düşüncesinin Teşekkül Devri; çev. E.R. Fığlalı, (Ankara: Umran Yay, 1981), 44.
} 
yollarla değerlendirmeye tabi tutmayı kınama anlamına gelmiştir. Bid'atleri ret de ilerleme esaslarını ret olarak anlaşılmıştır. ${ }^{68}$

Selefi dil, bir tarzdan ziyade bir tepki hareketi ve bir mağlubiyet söylemi ya da naif bir hissiyatın dile getirilmesidir. Bu yüzden bütün selefi söylem çeşitleri, söylemini geçmişe, ilk İslam tecrübesine oturtmaya ne denli çalışırsa çalışsın, İslam medeniyeti ve kültüründen yoksun olduğu için, özü itibariyle güncel toplum mühendisliğinin ve marangozluğunun radikal şekli olmaya mahkûmdur. Selefiliğin geçmişi tam manasıyla geçmiş değildir. Bu zihniyette kısmi geçmiş, aynı zamanda hizaya sokulmuş, idealleştirilmiş bir geçmiştir. Geçmiş idealliklere dönmek imkânsızdır, çünkü böyle bir şey yoktur. Nihayetinde selefi düşüncenin Selefilik hayali ve soyut bir ümmete atıfta bulunmaktadır. Bu durum beraberinde kültürsüzleşmeyi getirmektedir. Selefi anlayışlarda şeriat ve yasa üzerindeki kesin vurgu bu yüzdendir. SSeriat kültürün yerini tutmaktadır. Selefi zihniyet, ahlak zabıtalığını kültürle karıştırmaktadır. Kültür yerine yasa! Tarih selef devrine hiçbir şey katmamışsa İslam, kapalı bir ayin, zorunluluk ve yasaklar bütünü olacaktır. Tarih yoksa kültür de yoktur. 69

Tarihte ortaya çıkan tüm selefi yönelişlerde selefin ve sünnetin otoritesine dayanmak suretiyle mevcut ilerleme koşullarının reddi söz konusu olmuştur. Bu zihniyette din bir dişlama aracıdır. Hatta bir tehdit aletidir. Selefilikte korunma içgüdüsüyle silahlar çoğaltılmış, güce çevirmek için dinin ruhu alabildiğine budanmıştır. Bu hareketlerde din, belli bir kültürel aidiyetin korkularının kullandığ1 bir fren haline gelmiştir. Değişimden korkanlar, eskinin değerlerine ve simgelerine sığınacak ve tepkiyi esas alan bir din projesi geliştireceklerdir. Selefilik durağan kabilevi toplum yapısının, en küçük değişime bile isyan eden bir İslam anlayışında kendini temellendirmesi, korkak, bağnaz, sert bir dinde yansıma bulmasıdır. Selefilik

\footnotetext{
68 İşcan, Selefîliğin Temel Esasları ve Sosyo-Politik Arka Plan”, Tarihte ve Günümüzde Selefîlik Milletlerarası Tartışmalı İmî Toplantı (08-10 Kasım 2013), (2014), 107.

69 Roy, Küreselleşen İslam, 134-143.
} 
dinin otorite imgesini bozmuştur. Çünkü bu anlayışta din, korkunun adeta toplumsal örgütlenmesi haline gelmiştir. İnanç belli bir topluluk ile ilişkilendirilir ve bir kimlik göstereni olduğunda köktenleşmekte böylece dinin evrenselliği yok edilmiş olmaktadır. ${ }^{70}$

İhya ya da islah, grubu, 'düşman'la ilgili olabilecek adlardan arındırmaya yönelik çabalar olarak algılanmış, dinî düşüncede aklın hâkimiyetine karşı bir protesto özelliği sergilemisstir. Bu anlamda ihya, 'paylaşılan bir endişe'nin grup üyeleri arasında toplumsal bir gerileme yaratmasına tekabül etmiştir. Bir tür anakronizm olarak anlaşılan ihya, bunalım zamanlarının nevzuhur çocuğu ve zorunlu ilk tepki biçimidir. Zamanını şaşıran, tarih ve zaman duygusunu kaybeden bütün ihya biçimleri, yenilgi psikolojilerini kışkırtmakla, hortlatmakla ve hâkim kültürü, farkında olmaksızın tersinden yeniden üretmekle ve meşrulaştırmakla sonuçlanır. Bu söylemlerin hepsinin ortak paydaları, aksiyoner değil, reaksiyoner olmaları, özgüven duygusu ile değil, yenilgi psikolojisi ile hareket ediyor olmalaridır. ${ }^{71}$

\section{Afgânî ve Abduh'un Görüşleri}

İhya hareketine "nereden başlamalı" sorusuna verilen İslâmcı cevaplarda önemli farklılıklar vardır. Bu bağlamda Afgânî (ö.1897) özgürlük ve inkılâbın esas alınmasını ileri sürer. O, ömrünü ülke ülke dolaşarak geçirmiş, gittiği yerlerde siyasal faaliyetlere ya bizzat katılarak ya da danışmanlık yaparak müdahale etmiştir. Öğrencisi Muhammed Abduh (ö.1905) ise siyasete mesafeli durmuştur. O, 1slahatçı bir mantıkla kurumların iyileştirilmesi, eğitimde reforma gidilmesi, kabiliyetli öğrenciler yetiştirilmesi, dini düşüncenin saf hale getirilmesi, dini meselelere modern çözümler üretilmesi gibi konular üzerine yoğunlaşmıştır. Abduh'un öğrencisi Reşid Rıza (ö.1935) ise hocasının ölümünden sonra onun modernleşme yanlısı

\footnotetext{
70 İşcan, "Selefîliğin Temel Esasları ve Sosyo-Politik Arka Plan", 107.

71 İşcan, "Selefiliğin Şiilik Değerlendirmeleri Bağlamında Nefret ve Şiddet Söylemi”, 159.
} 
1slahat çizgisini terk ederek, kendisine miras kalan Menâr ekolünü daha siyasal, aynı zamanda muhafazakâr ve selefî bir çizgiye yerleştirmiştir. İhyacı şahsiyetlerin hangi ağırlık ve üslupta geleneği sorguladıkları veya lâdinî mihraklara karşı reaksiyoner olup olmadıklar1, onların modernist ya da muhafazakâr olarak değerlendirilmelerinin kıstaslarıydı. Meselâ Ahmed Han (ö.1898) ve Afgânî'nin ikisi de modernist ve akılcı olmasına rağmen, Ahmed Han'ın natüralist görüşleri, Afgânî'nin bile tahammül edemeyeceği ve reddiye yazacağı derecede aşırı düzeylerdeydi. ${ }^{72}$

Afgânî, genellikle ihyacıllğın ilk ve asıl kuramcısı olarak takdim edilmektedir. Afgânî 1slahat programında İslâm birliği fikrinin çok önemli bir yeri vardır. Ona göre bu birliğin başında mutlaka bir halife bulunmalıdır. Ancak yönetim, ümmetin katılımı ve meşveret usulü ile yürütülmelidir. Batının körü körüne taklidi asla çözüm değildir. Ancak batı, güç ve hâkimiyetin sırlarını keşfetmiş ve bunları yerli yerinde kullanarak ilerlemiştir. Bu sırların başında, düzen, sabır ve sebat gelir. Müslümanların bu değerleri alıp gelisstirmeleri gerekir. Müslümanlara dinleri hususunda taassupkâr olmalarını öneren Afgânî, batı karşısındaki aşağılık kompleksini anlamsız bulur ve Ortaçağ'ın üstün İslâm medeniyetini hatırlatır. Ona göre saltanat sistemi, batınîlik, kadercilik, hadis uydurmacılığı, medrese sisteminin bozuluşu, cehalet, amelsizlik gibi etkenlerle medeniyet duraklamış, sonra da gerilemeye başlamıştır. Bu süreci ilerlemeye doğru çevirmek, sistemli bir 1slahat projesiyle mümkündür. Afgânî' 1slahatta önceliği siyasi çalışmalara vermektedir. O hayatında, yönetimden yani tavandan başlayıp tabana doğru inen hızlı bir toplumsal iyileştirmeyi sağlayacak faaliyetlere öncelik vermiştir. M1sır'da İhvân-1 Müslimîn, Pakistan'da Cemaat-i İslâmî gibi siyasal örgütlenmeler, Afgânî"nin 1slahat çabalarını tekrarlayan hareketler olarak değerlendirilebilir. ${ }^{73}$

\footnotetext{
72 Büyyükkara, Çağdaş İslami Akımlar, 28.

${ }^{73}$ Hayreddin Karaman, "Efgani, Cemaleddin”, DİA, 10: 461-462; Büyyükkara, Çağdaş İslami Akımlar, 31-32. Ayrıca detay için bkz. Keddie, Cemaleddin Efgani, $147 \mathrm{vd}$.
} 
Afgânî dini 1slah projelerinde metot ve anlayış olarak siyaseti öncelediği için onun 1slah projesinin tavandan-tabana doğru ${ }^{74}$ bir eğilim olarak tanımlamak mümkündür. Bu yaklaşım konjonktür itibariyle kulağa hoş gelmesine ve kendinden sonraki 1slah projelerini siyaset merkezinde inşaya gayret eden Cemaat-i İslam gibi bazı akımları etkilemiş olsa da kendisini halka mal ettirmede yeterince başarılı olamamıştır. Bunda Afgânî'nin ismi, nesebi ve mezhebi üzerinde yapılan spekülasyonların da katkısı olduğu ifade edilmelidir.

Muhammed Abduh'ta dini 1slah düşüncesinde selef akidesine dönüş çağrısı sıklıkla görülmektedir. Abduh, ihtilaflar çıkmadan önceki Selefin anladığı metotla dini anlamanın ve onu ilk kaynaklarına müracaatın temel amacı olduğunu söyler. ${ }^{75}$ Fakat Abduh seleften bahsederken sadece Hz. Peygamber ve ashabından oluşan ilk nesli kastetmez; onu daha genel anlamda gelişme dönemindeki Sünni İslam'in merkezi geleneğine atıfta bulunmak için kullanır. O’na göre İslam'in üçüncü ve dördüncü yüzylllardaki büyük kelamcılar1, Eş’ari (ö.324/936), Mâturidî (ö.333/944), Bâkıllânî (ö.403/1013) de seleftendi.76 O'nun selefe dönüş çağrısı toplumsal 1slahı gerçekleştirmek için kullandığı bir vasıtadır. Bu konuda Abduh, İbn Teymiyye ve Muhammed b. Abdilvehhab'dan etkilenmiş olabilir. Fakat metot ve uygulama bakımından onlardan ayrılmaktadır. Abduh selef dönemini kutsallaştırmamış ve yeniliklere karsı çıkmada İbn Teymiyye ve İbn Abdilvehhab kadar katı olmamıştır. ${ }^{77}$

Abduh'un ana hedefi ise ilk kaynaklarından hareketle dinin anlaşılmasını sağlamak; itikadı asr-1 saâdet'teki saflığına kavuşturup onun akıl ve ilimle ilişkisini güçlendirmek; değişen dünya şartlarında dinin rolünü tekrar etkinleştirmektir. Çağdaş bir İslâm düşüncesi kurabilmek için modern batı ile ilişkilerin geliştirilmesini düşünür; batıdan bilim ve tekniğin alınmasını teşvik ederken dine uy-

\footnotetext{
74 Büyyükkara, Çağdaş İslami Akımlar, 32.

75 Muhammed Ammara, el-A'malü'l-Kamile li'l-İmam Muhammed Abduh, (Beyrut 1980), 2: 318.

76 Albert Hourani, Çağdaş Arap Düşüncesi, 169-170.

77 İşcan, Muhammed Abduh, 224.
} 
mayan taraflarından uzak durulmasını ister. Abduh, kader meselesinde, insanın iradesi ve kesbine Eş'arî anlayıştan daha fazla değer vererek Mâturîdîliğe yaklaşmıştır. Kur'an'ın insanların ilmi ve ahlaki seviyelerini yükseltmek için indirildiğini söylemiş, onun ölü ve hastalara okunan bir kitap haline getirilmesini eleştirmiştir. Dinin anlaşılmasında Kur'an'a merkezi bir rol biçip sünnetin delaletini büyük ölçüde ihmal etmesiyle geleneksel selefilikten ayrı düşmüştür. Bazı ayetleri kendi zamanındaki bilimsel verilere uygun olarak yorumlamaya çalışmıştır. Fikıhta ictihadı savunmuş, fetva ve kazâda maslahat prensibinin işletilmesini önermiştir. Kutsama kastıyla olmaksızın heykel yapımına, şapka gibi batılı kıyafetlerin giyilebileceğine; Ehl-i Kitab’n kestiğinin yenilebileceğine verdiği ruhsatlar, dönemin bazı ilim adamları tarafından tenkit edilmiştir. ${ }^{78}$ Söz konusu fikriyâtı ve yöntemiyle Muhammed Abduh, siyasal olmaktan çok kültürel karakterli, tabandan tavana ${ }^{79}$ doğru bir toplumsal inşay1 öngören 1slah hareketlerinin model aldığı bir öncü olmuştur. Eğitim, okullaşma, basın yayın gibi faaliyetler üzerine yoğunlaşan, bu faaliyetlerin gelişmesi ve zarar görmemesi için, değişken nitelikli siyasetten uzak durmayı yeğleyen günümüz dini hareketleri ile Abduh'un yöntemi arasında bariz benzerlikler bulunmaktadır. Bu arada $\mathrm{Ab}-$ duh'un din anlayışının modern motifler taşıdığı gözden kaçmamaktadir. 80

Afgânî ve Abduh çizgisindeki bir 1slah anlayışı, batı ile İslâm dünyası arasındaki açıklığın kapatılabilir olduğunu düşünmekte, hiçbir manevi değişime ihtiyaç duymadan, sadece batı teknolojisini almakla sorunların halledilebileceği anlayışına sıcak bakmamaktadır. Onlara göre bir ihyadan bahsedebilmek için zihniyet ve ahlâk

78 Said Özervarl1, "Muhammed Abduh", DİA, 30: 484.

79 Büyyükkara, Çağdaş İslami Akımlar, 34.

80 Abduh'un görüşleri hakkında detay için bkz. İşcan, Muhammed Abduh'un Dini ve Siyasi Görüşleri, (İstanbul: Dergâh Yay, 1998), 299 vd.; Fazlur Rahman, İslam ve Çăgdaşlık: İslam Eğitim Tarihinde Fikri Bir Geleneğin Değişimi, çev. A. Açıkgenç-M. H. Kırbaşoğlu, (Ankara: Fecr Yay, 1990), 158; Rukiye Koçak, Muhammed Abduh'ta Selefi Eğilimler, (İstanbul: M.Ü. Sosyal Bilimler Enstitüsü, 2006), 26-97. 
değişimine ihtiyaç vardır. Dolayısıyla onlar, entegrist bir tavır takınmamış, kendi kendine yeterli olma, İslâmî olmayan her şeyden kuşkulanmayı içine alan âdeta "değişmeyen durağan dünya" görüşüne meyletmemişlerdi. ${ }^{81} \mathrm{Bu}$ düşünce yapısı için, klasik İslâm çağdaşçılığ ya da ihya hareketi batıya açılımdan, yapıcı bir diyalogdan, ortak kelimelerde buluşmadan yanadır. Bu ekolü meşgul eden asıl mesele, modernitenin İslâm ile uzlaşabilirliğidir. Moderniteden kaçış olamayacağını zımnen de olsa belirten İslâm modernizmi, Müslüman toplumun yüz yüze geldiği sorunun bu yüzden, modern olup olmamak şeklinde betimlenemeyeceğini, çünkü hakikaten başka seçenek olmadığını belirtmişler ve soruyu şu şekilde sormuşlardır: Bir insan aynı zamanda hem modern hem de Müslüman olabilir mi? Ve bu soruya tek sesli olmayan bir 'evet' ile karşıllik vermişlerdir. ${ }^{82}$ Ayrıca İslâm modernizmi serbest kültür değişiminin' meşruluğunu garanti altına almak maksadıyla açık bir şekilde din ve dünya ayırımı yapmış, dinin ilgi sahasını, maneviyat ve ahlâk ile sınırlandırma yoluna giderek, varlık alanında, insanın İslâm tarafından tamamen özgür bırakıldığını ortaya koymuştur. ${ }^{83}$

\section{Sonuç}

Islah/ihya çabalarının ulaşılan hali hazırdaki durumu İslam düşüncesini ya da toplumlarını mevcut krizlerden çıkarmaya yönelik, yerine göre abartılı anlamlar yüklenerek, ontolojik bir çaba olarak görülebilir. Soruna ontolojik bir arayış olarak bakanlar, ihya/1slah faaliyetlerini olmazsa olmaz olarak kabul ederlerken; epistemolojik bir çıkışı önceleyenlere göre ise ihya faaliyetleri, varlık yokluk değil,

${ }^{81}$ Geniş bilgi için bkz. İşcan, Muhammed Abduh'un Dinî ve siyasi Görüşleri, (İstanbul: Dergah Yay., 1998), 246-256.

82 Charles J. Adams, "Fazlurrahman ve Klasik Modernizm”, İslâm ve Modernizm "Fazlurrahman Tecrübesi" (22-23 Şubat 1997), (İstanbul: 1997), 85.

83 Bkz. M. Zeki İşcan, "Çağdaş Bir Düşünür Olarak Muhammed Abduh ve Siyasi Görüşleri”, İslâm'in Bugünkü meseleleri, (Ankara: Türk Yurdu Yay., 1997), 333-345. 
İslam'ın bir bütün olarak kendisini ifade etmesiyle ilgili bir konudur.

Görülebildiği kadarıyla İslam tarihinde görülen ihya ya da 1slah çabaları, yeni durumları anlama olarak ortaya çıkmamış, aksine bir geriye dönme sadedinde kalmıştır. Islah projeleri, her yeniliğin saflığ1 bozduğu, her türlü değişikliğin İslam kimliği üzerinde krizlere yol açtığı inancını taşımıştır. Bu yüzden tecdit, 1slah veya ihya, kendinden bilinçli bir yenilenme isteği ya da gelecekteki bir ütopya ümidinin itmesinden ziyade, geçmiş bir deneyimin örneğinden esinlenmek sadedinde kalmıştır. ${ }^{84}$

Islah hareketlerinin selefe dönüş çağrısının yalnız teolojik bir çağrı olduğunu düşünmek, en azından Vehhâbiliğinin tarih sahnesine çıkarken hedeflediği düşünce yapısını anlamamak demektir. Zira Muhammed b. Abdilvehhab'in dinde 1slah fikri, daha çoğulcu bir din anlayışı temsil eden Osmanlı hilafet düzenine karşı isyan hareketlerinin dini temelini oluşturmuştur. Onun bid'at, şirk ve gerçek tevhit üzerinde duruşu, dini aslına irca üzerinde yoğunlaşması, selef dönemine dönüş çağrısı, siyasi açıdan şu manaya gelmekteydi: Osmanlı hilafeti gerçek dini temsil etmemektedir. Bu yüzden Osmanlı'ya karşı ayaklanmak vaciptir. Vehhâbilik Osmanlı yönetimine karşı ayrılıkçı bir mücadeleye kaynaklık etmiştir. Vehhâbiik, çok fazla farklılaşmamış bir topluluğun, yerleşik yüksek kültürü temsil eden Osmanlı'ya karşı tepkiselliğini ifade etmekte$\operatorname{dir} .85$

Afgânî ile başladığ kabul edilen ve Abduh'la sistematik bir özellik kazanan İslâm modernizmi İslâm dünyasında gereken ilgiyi maalesef görmemiş, Reşit Rıza, Abduh'un önemli bir talebesi olduğu söylenmesine rağmen, ihya hareketini selefiliğe dönüştürmüştür. ${ }^{86}$ Selefiliğin Vehhâbilikle angaje olması, bu hareketi, zihniyeti

\footnotetext{
${ }^{44}$ Bkz. Nilüfer Göle, İslam ve Modernlik Üzerine Melez Desenler, (İstanbul: Metis Yay, 2000), 23.

85 İşcan, "Selefîliğin Temel Esasları ve Sosyo-Politik Arka Planı", 92.

86 Meryem Cemile, İslâm ve Çağdaş Öncüleri, çev. S. Ayaz, (İstanbul: Bir Yay, 1986), 225-227.
} 
Vehhâbilik üzerinden okumaya ve değerlendirmeye yol açmıştır. Siyaseten birbirlerini var etme noktasında olan selefi zihniyet ile Vehhâbiliğin bu ilişkisi, selefiliği siyasetten azade kalarak anlama çabalarını zorlaştırmaktadır. Öncelik siyaset olunca karşılaşılan sorunlara sağliklı cevaplar verilememekte, kolay genelleme ve dişlamacı söylemeler üretilmektedir. Ancak Afgânî ve Abduh çizgisinin daha soğukkanlı, İslami düşüncenin yeniden ihyası noktasında hala tazeliğini koruyan sorular sorduğu ve sağl1klı perspektifler geliştirdiği söylenebilir. Bu çizgi, özellikle ekonomik bir güç halini aldıktan ve rejim ihracı parolasıyla selefiliği Vehhâbi etiketiyle pazarlamaya çalışan Vehhâbiliğin Afgânî çizgisi aleyhindeki faaliyetleri, 1967 Arapların İsrail karşısında yenilgi yaşamaları nedeniyle acil olarak ideoloji gömleği giydirilen isyan hareketleri meselelere duyarlı ve soğukkanlı yaklaşma yeteneklerini kaybetmelerine neden olmuştur.

İslam modernizmi ya da ihyacılığı, sonraki süreçlerde siyasal İslam, cihadçı selefilik ve benzeri farklılaşmalarıyla temsil edilen gruplara göre İslam'ı salt bir ideoloji olarak görmemiştir. Oysa ikinci grupta yer alan hareketlerde İslam tam anlamiyla bir ideoloji görevi ifa etmiştir, etmektedir. İlk ihya hareketlerinde maruz kalınan şoklara karşı nasıl cevap verileceği ve İslam toplumlarının karş1 karşıya oldukları siyasal ve kültürel batı kuşatmasından nasıl kurtulacağ1na dair çeşitli sorular sorulurken, sonraki siyasal İslamcı hareketlerde İslam her şeyin kendinde olduğu, tüm hakikatleri kuşatan her türlü soruna ve soruya cevap veren/verebilen bir yapı olarak alg1lanmıştır. Sonuç itibariyle her türlü medeniyeti ve kültürel etkileşimi hatta İslam'ın farklı tonlarını yaşayan grupları dahi dişlayan içe kapanma, entegrizm gerçekleşmiştir.

İhya çabalarının sonuçsuz kalmasının en önemli nedenleri arasında onların geçmişi olduğu gibi günümüze taşıma, geçmişi bir prototip olarak düşünerek mevcut krizlerin çıkışında tarihi bir birikimin çıkıs noktası olarak görme arzusu da nedenler arasında sayılabilir. Çözümün Kur'an ve sahih sünnetin ahlak eksenli okunuşunda aranması önemli katkılar sağlayabilirdi. Şahıs ve kavram merkezli oluşturulan tarihi paradigmalar bu iki değerin önüne geçi- 
rilmiş, ihyacıların din anlayışları ahlaki değil ontolojik boyutta kalmıştır. İslam öncelikle ahlak eksenli bir dindir, yani insan birey olarak kendi farkına vardıktan sonra Allah'ın emirleriyle bütünleşmeye çalışmaktadır, din bir hayat tarzıdır. Oysa ontolojik din anlayışında ise adeta bireyi Allah ile bütünleşmeye zorlanmakta, adeta Allah karşısında bir konum almaya yönlendirilmektedir. Yani ihyacıların dini anlayışları, doğal olarak onların ıslah düşüncesinin tarzına ve yöntemine etki etmiştir.

İhya/1slah hareketlerinin tüm kesimlerce kabulünü kolaylaştırması bakımından, kavramlara dayalı bir ihya sürecinin olması gerekir, çünkü kavramlar üzerinden yüründüğünde simgelerin ve söylemlerin gücü azalırken, ideolojik bir yaslanma alanı olarak kullan1lan tarihin suiistimal edilmesinin de önüne geçilecektir. Aksi halde ileri sürülen ihya 1slah çabaları şekilcilikten öteye geçemeyecektir.

Görülebildiği kadarıyla ihya/1slah hareketleri, araştırmacılarda genel bir eğilim olarak Mısır ve civarı merkeze alınarak incelenmektedir. Bu durum, İslam düşüncesinin siyasi ve fikri taşıyıcı aktörü olan Osmanlı döneminin ihmal edilmesine neden olmaktadır. Özellikle 1870'lerden sonraki süreçlerde Osmanlı'da dini ihya hareketlerinin ve Vehhâbiliğin mezhepler tarihi perspektifinden tekrar okunması, akademik düzeyinde çalışmaların yapılması gereği ortadadir.

Günümüzde İslam'ın görünür enstrümanlarından ya da işlevsel olduğu için hâkim paradigmalar tarafından ısrarla gündemde tutulan radikal İslamc1 grupların oluşturduğu İslam imgesi, oldukça sorunlu bir tipoloji ortaya koymaktadır. Bu sorunun çözülmesi gerekmektedir. Bunu yaparken de özellikle Vehhâbilikle irtibatı nedeniyle yayılmacı bir karakter taşıyan selefiliği batılı kaynaklardan hareketle, oryantalist bir perspektifle değil, onu kendi düşünce sistemimizin bir parçası olarak ele almak; başta Ebu Hanife ve İmam Mâturdî olmak üzere İslam düşünce geleneği içerisinde vahyin kontrolünde aklın işlevsel kılınmasına katkı sağlayan her fikirden istifadeye açık bir duruş sergilenmelidir. Özellikle Afgânî ve Abduh'un düşünceleriyle selefi zihniyet arasında kurulacak bir irtibatın onların İslam düşüncesinin yeniden ihyası konusundaki önemli 
görüşlerinin anlaşılmasına zarar vereceği ihtimalini unutmamak gerekmektedir.

\section{Kaynakça}

Abduh, Muhammed. el-İslâm Dînu'l-ilm ve'l-medeniyye. thk: Tahir et-Tenâhi. Kahire: ty.

Adams, Charles J. "Fazlurrahman ve Klasik Modernizm”. İslâm ve Modernizm "Fazlurrahman Tecrübesi. (22-23 Şubat 1997), İstanbul: 1997 .

Ammara, Muhammed. el-A'malü'l-kamile li'l-İmam Muhammed Abduh. Beyrut: 1980.

Ammara, Muhammed. el-Imam Muhammed Abduh: Müceddidü'ddünya bi tecdidi'd-din. Beyrut: 1985.

el-Behiy, Muhammed. İslami Direniş ve Islahat. çev. İbrahim Sarm1ş. İstanbul: 1997.

Bodur, H. Ezber. Dinî İhya Hareketi Olarak Vahhabiliğin Doğuşu, Gelişmesi, Sosyo-Politik, Ekonomik Neticeleri. Doktora Tezi, Atatürk Üniversitesi, Erzurum: 1986.

Büyükkara, Mehmet Ali. "Günümüzde Selefîlik ve İslâmî Hareketlere Olan Etkisi”. Tarihte ve Günümüzde Selefílik (Milletlerarası Tartışmalı İlmî Toplantı 08-10 Kasım 2013,) 485-524. 2014.

Büyükkara, Mehmet Ali. Çağdaş İslami Akımlar, İstanbul: Klasik Yayınlar1, 2015.

el-Cabiri, Muhammed Abid. Arap Aklının Oluşumu, çev. İbrahim Akbaba. İstanbul: 1997.

el-Cabiri, Muhammed Abid. Arap-İslam Kültürünün Akıl Yapısı, çev. B. Köroğlu-H. Hacak-E. Demirli. İstanbul: 2000. 
Cemile, Meryem. İslâm ve Çağdaş Öncüleri. çev. S. Ayaz. İstanbul: Bir Yayıncilik, 1986.

Cioran, Emile. Tarih ve Ütopya. çev. Haldun Bayrı. İstanbul: metis Yay, 2013.

Eliaçık, R. İhsan. Adalet Devleti: Ortak İyinin İktidarı. İstanbul: İnşa Yayınları, 2011.

Eşref Edib. "Dinde Reformcular", Dinde Reformcular. haz. E. Edib, A. F. Başgil, N. Topçu vd. İstanbul: Sebilurreşad Neşriyat1, 1959.

Fığlalı, Ethem Ruhi. Çağımızda İtikadi İslâm Mezhepleri. Ankara: 1996.

Frayer H. Din Sosyolojisi. çev. T. Kalpsüz. Ankara: 1964.

Göle, Nilüfer. İslam ve Modernlik Üzerine Melez Desenler. İstanbul: Metis Yayınları, 2000.

Hourani, Albert. Çağdaş Arap Düşüncesi. çev. L. Boyac1-H. Yılmaz. İstanbul: 2000.

Hüseyin Kazım Kadri. Türk Lugati. İstanbul: 1928.

İbn Abdilberr. Camiu Beyani'l-İm ve Fadlihi ve ma Yenbağî fi Rivayetihi ve Hamlihi. thk. Abdulkerim el-Hatip. Kahire: Dâru'lKütübi'l-İslâmiyye, 1982.

İbn Ebül-İz, Ali b Ali b Muhammed ed-Dımaşki. Şerhu't Tahaviyye fi'l Akideti's- Selefiyye. Beyrut: 1988.

İbn Manzur, Ebül-Fazl Muhammed b Mükerrem b Ali el-Ensârî. Lisanü'l-Arab. Beyrut: Dâru Sadır, t.y.

İbn Teymiyye. Ebü'l-Abbas Takıyyüddin Ahmed b Abdülhalim. Mecmüu Feteva, Riyad: 1991. 
İbn Teymiyye. Akidetü Ehli’s-Süne ve'l- Firkati'n-Naciye. Mısır: 1385.

İnayet, Hamit. Arap Siyasi Düşüncesinin Seyri. çev. Hicabi Kırlangıç. İstanbul: Yöneliş Yayınları, 1991.

İşcan, Mehmet Zeki. "Çağdaş Bir düşünür Olarak Muhammed Abduh ve Siyasi Görüşleri”, İslâm'ın Bugünkü meseleleri. 333345. Ankara: Türk Yurdu Yayınları, 1997.

İşcan, Mehmet Zeki. Muhammed Abduh'un Dini ve Siyasi Görüsleri. İstanbul: Dergâh Yayınları 1998.

İşcan, Mehmet Zeki. Selefilik: İslami Köktenciliğin Tarihi Temelleri. İstanbul: Kitap Yayınevi, 2006.

İşcan, Mehmet Zeki. "Gazali'nin İhya ve Islah Düşüncesine Genel Bir Bakış”. Diyanet İlmi Dergi, 47 sy. 3 (2011): 115-134.

İşcan, Mehmet Zeki. "Batıcıların İslamcıllı̆ı "Hüseyin Cahit ve Cela Nuri'nin İslami Yenilik Düşüncesi”. Düşünce Dünyasında Türkiz, 3 sy. 14, (2012).

İşcan, Mehmet Zeki. "Selefiliğin Şiilik Değerlendirmeleri Bağlamında Nefret ve Şiddet Söylemi”, e-makâlât Mezhep Araştırmaları, 6 sy. 2 (2013): 151-172.

İşcan, Mehmet Zeki. "Selefíliğin Temel Esasları ve Sosyo-Politik Arka Plan", Tarihte ve Günümüzde Selefîlik Milletlerarası Tartışmalı İlmî Toplantı (08-10 Kasım 2013), 91-110. 2014.

İşcan, Mehmet Zeki. Dinî "Bir Otorite Olarak Sahâbe Algısı". İslâm Medeniyetinin Kurucu Nesli Sahâbe: Sahâbe Kimliği ve Algısı, Tebliğ ve Müzâkereler, Tartışmalı İlmî Toplantı, (27-28 Nisan 2013), 205-218. 2014.

Kara, İsmail. Türkiye'de İslamcllı Düşüncesi'nin Temel Metinleri. Gerçek Hayat Dergisi, (ty. yy.) 
Karaman, Hayreddin. "Efgani, Cemaleddin". DİA, 10: 456-466, İstanbul: 1994.

Karpat, Kemal. İslam'in Siyasallaşması. çev. Şiar Yalçın. İstanbul: Bilgi Üniversitesi Yay, 2001.

Keddie, Nikki, Cemaleddin Efgani: Siyasi Hayatı, çev. Alaeddin Yalçınkaya. İstanbul: Bedir Yayınları, 1997.

Koçak, Rukiye. Muhammed Abduh'ta Selefi Eğilimler. Yüksek Lisans Tezi, Marmara Üniversitesi, İstanbul: 2006.

Korkmaz, S1ddık. "Selefiliğe Karşı Reddiyeler", Tarihte ve Günümüzde Selefîlik Milletlerarası Tartışmalı İmî Toplantı (08-10 Kasım 2013), 449-482. 2014.

Maraş, İbrahim. "İslam Dünyasında Yenileşme Arayışları". İslam Düşünce Ekolleri Tarihi. Editör. Hasan Onat. 396-419. Ankara: Ankuzem, 2005.

Mevdudi, Ebu'l-Ala. İslâm'da İhya Hareketleri. çev. A. Ali Genç. İstanbul: Pinar Yayınları, 1986.

Müfrih b. Süleyman el-Kavsi. el-Menhecü's-Selefi. Riyad: Daru'1Fazile, 2002.

Onat, Hasan. "İslâm Ortak Paydasını Kaybetmiş Müslümanların Açmazı: Şi'î-Selefî Kutuplaşması”. Tarihte ve Günümüzde Selefïlik Milletlerarası Tartışmalı İlmî Toplantı (08-10 Kasım 2013), 525-551. İstanbul: 2014.

Özervarl1, Said. "Muhammed Abduh”. DİA, 30: 482-487. İstanbul 2005.

Rahman, Fazlur. İslam ve Çağdaşlık: İslam Eğitim Tarihinde Fikri Bir Geleneğin Değişimi. çev. A. Açıkgenç-M. H. Kırbaşoğlu. Ankara: Fecr Yayınları, 1990.

Roy, Olivier. Küreselleşen İslâm. çev. Haldun Bayrı. İstanbul: Metis Yayınları, 2003. 
Şahin, Hanifi. İk Dönem Şii Kaynaklarda Sünni Algısı, Ankara: Berikan Yayınları, 2015.

Şehristani, Ebü'l-Feth Taceddin Muhammed b. Abdülkerim. el-Milel ve'n-Nihal. Beyrut: 1980.

Tehânevî. Kitabu Keşşafi Istılahati’l Fünûn. İstanbul: 1984.

Türköne, Mümtazer. "İslamc1l1k", DİA, 23: 61-62. İstanbul: 2001.

Waardenburg, T. "Official and Popular Religion in Islam". Social Compass. 5, sy. 25, 1978: no. 3-4.

Watt, W. Montgomery. İslam Düşüncesinin Teşekkül Devri. çev. E. R. Fığlalı. Ankara: Umran Yayınları, 1981.

Yurdaydın, Hüseyin G. İslâm Tarihi Dersleri. Ankara: 1998.

Zeydan, Corci. Teracimu Meşâhîru'ş-Şark fi'l-Karni't-Tasi Aşere. Hindevi, Misır: 2012. 
